BBA 51761

\title{
POOL SIZES OF PRECURSORS FOR PHOSPHATIDYLCHOLINE FORMATION IN ADULT RAT LUNG TYPE II CELLS
}

\author{
MARTIN POST ${ }^{a}, \mathrm{~b}, *$, JOSEPH J. BATENBURG ${ }^{a}$, BARRY T. SMITH ${ }^{\mathrm{b}}$ and LAMBERT M.G. VAN GOLDE ${ }^{\mathrm{a}}$ \\ "Laboratory of Veterinary Biochemistry, State University of Utrecht, P.O. Box 80177, 3508 TD Utrecht (The Netherlands) \\ and ${ }^{b}$ Department of Pediatrics, Harvard Medical School, 75 Francis Street, Boston, MA 02115 (U.S.A.)
}

(Received 16th April, 1984)

Key words: Phosphatidylcholine; Pool size; Lung surfactant; (Adult rat type II cell)

1. The pool sizes of the choline intermediates and cofactors involved in the CDPcholine pathway were studied in alveolar type II cells from adult rat lung. 2. The choline phosphate pool was much larger than both the choline and CDPcholine pools. 3. Kinetic analysis of the pool sizes revealed that cholinephosphate cytidylyltransferase catalyzes a non-equilibrium reaction. 4 . These results are consistent with the idea that cholinephosphate cytidylyltransferase regulates the choline flux into phosphatidylcholine in adult rat lung type II cells.

\section{Introduction}

Phosphatidylcholine is the principal component of pulmonary surfactant which stabilizes the lung by lowering the surface tension at the alveolar surface [1]. The de novo synthesis of phosphatidylcholine in the lung proceeds predominantly via the CDPcholine pathway [2]. The regulation of biosynthesis of phosphatidylcholine in the lung has not been elucidated. Several studies suggest that, in the lung [3-6], as in other tissues [7], cholinephosphate cytidylyltransferase catalyzes a rate-limiting step in the de novo synthesis of pulmonary phosphatidylcholine. Because these studies were carried out with preparations of whole lung, the results are not necessarily applicable to type II cells, the producers of pulmonary surfactant [8]. Recent studies [9] with isolated type II cells from adult rat lung on the uptake of [Me${ }^{14} \mathrm{C}$ choline and its incorporation into its metabo-

* To whom correspondence should be addressed at: Joint Program in Neonatology, 75 Francis Street, Boston, MA 02115, U.S.A. lites indicated that in these cells the choline phosphate pool was much larger than the CDPcholine pool, suggesting that the formation of the nucleotide may be limited. This suggestion was supported by the results of pulse-chase experiments with labelled choline [9]. In order to evaluate further the possible rate-limiting role of cholinephosphate cytidylyltransferase in the formation of phosphatidylcholine by adult type II cells, we decided to measure the pool sizes of the intermediates and cofactors involved in the CDPcholine pathway in these cells.

\section{Methods}

\section{Materials}

All radioactive chemicals were obtained from New England Nuclear (Boston, MA). Choline kinase, phosphodiesterase, alkaline phosphatase, nucleoside monophosphate kinase and nucleoside diphosphate kinase were supplied by Boehringer (Mannheim, F.R.G.). AG1-X8 anion-exchange re$\sin$ in formate form was purchased from Bio-Rad (Richmond, CA). All other chemicals were sup- 
plied by Sigma Chemical Company (St. Louis, MO) or J.T. Baker Chemical Company (Deventer, The Netherlands).

\section{Isolation of type II cells}

Type II cells were isolated from lungs of male Wistar rats $(175-200 \mathrm{~g})$ by trypsinization, densitygradient centrifugation and differential adherence in primary culture [10-12]. After $20 \mathrm{~h}$ in culture, the cells were used for the measurement of the pool sizes. Purity and viability of the type II cells were of the same order as reported previously [13].

Analysis of the pool sizes of the choline-containing compounds in adult rat lung and type II cells isolated from adult rat lung

The lungs from the animals were quickly removed and frozen in liquid nitrogen. The frozen lungs were homogenized with 5 vol. cold methanol $/ \mathrm{H}_{2} \mathrm{O}(1: 1, \mathrm{v} / \mathrm{v})$ containing $3 \%(\mathrm{w} / \mathrm{v})$ trichloroacetic acid. The homogenate was transferred into centrifuge tubes and 5 vol. methanol/ chloroform $(1: 1, \mathrm{v} / \mathrm{v})$ were added. Subsequently, the lipids were extracted by the method of Bligh and Dyer [14]. Phosphatidylcholine was isolated from the lipid extract by thin-layer chromatography on silica gel $\mathrm{G}$ plates with chloroform/ methanol $/ \mathrm{H}_{2} \mathrm{O}(65: 35: 4, \mathrm{v} / \mathrm{v})$ as eluent [9]. The acid aqueous phase remaining after lipid extraction was extracted five times with 2 vol. diethyl ether to remove excess trichloroacetic acid. Hereafter, the aqueous phase was evaporated to dryness in a rotary evaporator. The residue was dissolved in water, and choline, choline phosphate and CDPcholine were separated by anion-exchange column chromatography as described below.

The cells, attached to the culture dishes, were washed three time with cold $0.25 \mathrm{M}$ sucrose $(\mathrm{pH}$ 7.4). The cells were harvested by scraping them in $3 \mathrm{ml}$ methanol $/ \mathrm{H}_{2} \mathrm{O}(1: 1, \mathrm{v} / \mathrm{v})$ supplemented with $3 \%(\mathrm{w} / \mathrm{v})$ trichloroacetic acid. After the addition of $3 \mathrm{ml}$ chloroform/methanol $(1: 1, \mathrm{v} / \mathrm{v})$, the lipids were extracted and phosphatidylcholine was isolated [9]. The aqueous phase remaining after lipid extraction was processed as described for the whole lung. Routinely, tracer quantities of radioactive choline-containing compounds were addded prior to homogenization or scraping and used to calculate recovery.

Choline, choline phosphate and CDPcholine were separated by chromatography on an AG1-X8 formate ion-exchange column $(60 \times 1 \mathrm{~cm})$ with a linear gradient of $0-0.03 \mathrm{M}$ ammonium bicarbonate.

Choline-containing fractions were pooled and the solvent was evaporated under reduced pressure. The dry residue was resuspended in $250 \mu 1$ of water. An aliquot of the resulting solution was assayed for choline content in a final incubation mixture containing $100 \mathrm{mM}$ glycylglycine ( $\mathrm{pH} 9.2$ ), $4 \mathrm{mM} \mathrm{MgCl}_{2}, 6 \mathrm{mM}$ ATP, $10 \mu \mathrm{Ci}\left[\gamma_{-}{ }^{32} \mathrm{P}\right] \mathrm{ATP}$ and 0.8 units per $\mathrm{ml}$ choline kinase. After $1 \mathrm{~h}$ incubation at $37^{\circ} \mathrm{C}$, the reaction was terminated by adding an equal amount of ethanol. The samples were applied to an AG1-X8 anionic resin in the formate form $(2.5 \times 0.5 \mathrm{~cm})$. The choline phosphate was eluted with $2 \mathrm{ml}$ of $0.1 \mathrm{M}$ ammonium bicarbonate. The radioactivity in choline phosphate was determined and choline content was calculated by comparison with a standard curve prepared with known amounts of choline [15]. The specificity of choline kinase for choline was tested by incubating the reaction mixture with ethanolamine instead of choline. No phosphorylation of ethanolamine was observed.

The choline phosphate pool size was determined after conversion of the choline phosphate to choline. After the anion-exchange column chromatography, the fractions containing choline phosphate were pooled and evaporated to dryness under reduced pressure. The residue was redissolved and incubated overnight at $37^{\circ} \mathrm{C}$ in $250 \mu \mathrm{l}$ of $0.2 \mathrm{M}$ Tris- $\mathrm{HCl}(\mathrm{pH}$ 8.9), $1 \mathrm{mM}$ magnesium acetate and 7.5 units of alkaline phosphatase. The reaction was terminated by boiling for $3 \mathrm{~min}$. The samples were then lyophilized, resuspended in water and assayed for choline content, as described above.

The CDPcholine pool size was measured after conversion of CDPcholine to choline by the sequential action of phosphodiesterase and alkaline phosphatase. The CDPcholine-containing fractions were pooled and dried under reduced pressure. The residue was redissolved in $250 \mu 1$ of $0.2 \mathrm{M}$ Tris- $\mathrm{HCl}(\mathrm{pH}$ 8.9) and $1 \mathrm{mM}$ magnesium acetate. Phosphodiesterase (0.04 units) and al- 
kaline phosphatase ( 7.5 units) were added and the samples were incubated overnight at $37^{\circ} \mathrm{C}$. The reaction was stopped by placing the incubation tubes in boiling water for $3 \mathrm{~min}$. The samples were lyophilized, resuspended in water and assayed for choline content, as described above.

\section{Other methods}

The phosphorus content of phosphatidylcholine was determined according to Bartlett [16]. DNA was measured by the method of Burton [17] as modified by Giles and Meyers [18] using calf thymus DNA as standard.

The ATP content was determined by the method described by Strehler [19]. The ADP pool size was measured indirectly. An aliquot of the aqueous phase remaining after lipid extraction was incubated in a buffer containing $75 \mathrm{mM}$ potassium phosphate (pH 7.4), $15 \mathrm{mM} \mathrm{MgCl}_{2}, 0.5 \mathrm{mM}$ phosphoenolpyruvate and 10 units pyruvate kinase. After $30 \mathrm{~min}$ incubation at $37^{\circ} \mathrm{C}$, the reaction was terminated by boiling, whereupon ATP was measured as described above. The ADP content was calculated by subtracting the ATP content mea sured directly.

The CTP pool size was assayed by the method of Choy et al. [20]. The CMP pool size was assayed after first converting CMP to CTP by the sequential action of nucleoside monophosphate kinase and nucleoside diphosphate kinase. An aliquot of the aqueous phase was incubated overnight at $37^{\circ} \mathrm{C}$ in a mixture containing $10 \mathrm{mM}$ Tris-suc- cinate ( $\mathrm{pH} 7.0$ ), $12 \mathrm{mM}$ magnesium acetate, 10 mM ATP, 0.05 units nucleoside monophosphate kinase, and 1 unit nucleoside diphosphatc kinasc. At the end of the incubation CTP was measured [20] and the CMP pool size was calculated by substracting the CTP content measured directly. When the assay was repeated in the absence of nucleoside monophosphate kinase, no CDP was detected. Therefore, the values reported represent primarily CMP.

Inorganic pyrophosphate pool sizes were determined according to the method of Putnins and Yamada [21].

Radioactivity was measured in a liquid scintillation mixture described by Pande [22]. Counting efficiency was determined by the channels ratio method.

\section{Results}

The concentrations of choline and its derivatives in whole lung and in type II cells are shown in Table I. It can be seen that the choline phosphate pool is much larger than the choline and CDPcholine pools in both whole lung and type II cells. Furthermore, the pool sizes of choline, choline phosphate and CDPcholine in the type II cells are at least an order of magnitude larger than those in whole lung. Compared to whole lung, the type II cells are also enriched in phosphatidylcholine content. This enrichment of phosphatidylcholine in type II cells is, however, less pronounced than the

\section{TABLE I}

POOL SIZES OT CIIOLINE-CONTAINING METABOLITES IN ADULT RAT LUNG AND TYPE II CELLS FROM ADULT RAT LUNG

The concentrations of choline-containing compounds were determined as described under Methods. Values represent means and S.E. for the number of experiments indicated in parentheses.

\begin{tabular}{|c|c|c|c|}
\hline & \multirow{2}{*}{$\begin{array}{l}\text { Whole lung } \\
\text { (nmol/g } \\
\text { wet wt) }\end{array}$} & \multicolumn{2}{|l|}{$\mathrm{pmol} / \mu \mathrm{g} \mathrm{DNA}$} \\
\hline & & Whole lung & Type II cells \\
\hline Choline phosphate & $247.4 \pm$ & $35.8 \pm$ & $2232.7 \pm 176.4(5)$ \\
\hline CDPcholine & $31.8 \pm 15.9(4)$ & $4.6 \pm 2.3(4)$ & $482.7 \pm 102.7(5)^{\mathrm{a}}$ \\
\hline Phosphatidylcholine & $17893 \pm 3343(6)$ & $2586 \pm 483 \quad(6)$ & $12500 \pm 991$ \\
\hline
\end{tabular}

a see Discussion. 
TABLE II

POOL SIZES OF COFACTORS INVOLVED IN THE CDP-CHOLINE PATHWAY IN ADULT RAT LUNG AND TYPE II CELLS TROM ADULT RAT LUNG

The concentrations of cofactors were determined as described under Methods. Values represent means and S.E. for the number of experiments indicated in parentheses. n.d., not detectable (less than $2 \mathrm{pmol} / \mu \mathrm{g}$ DNA).

\begin{tabular}{|c|c|c|c|}
\hline & \multirow{2}{*}{$\begin{array}{l}\text { Whole lung } \\
\text { (nmol/g } \\
\text { wet wt.) }\end{array}$} & \multicolumn{2}{|l|}{$\mathrm{pmol} / \mu \mathrm{g}$ DNA } \\
\hline & & Whole lung & Type II cells \\
\hline ATP & $721.2 \pm 190.0(4)$ & $104.2 \pm 27.4(4)$ & $188.2 \pm 56.4(4)$ \\
\hline ADP & $141.7 \pm 52.1(4)$ & $20.5 \pm 7.5(4)$ & $50.9 \pm 20.0(4)$ \\
\hline CTP & $53.5 \pm 10.1(4)$ & $7.7 \pm 1.5(4)$ & $190.0 \pm 30.0(3)$ \\
\hline CMP & $23.4 \pm 12.2(4)$ & $3.4 \pm 1.8(4)$ & $364.6 \pm 95.5(3)$ \\
\hline Inorganic pyrophosphate & n.d. & n.d. & n.d. \\
\hline
\end{tabular}

enrichment of the choline-containing metabolites. Since type II cells produce phosphatidylcholine with an unusually high percentage of disaturated molecules $[13,23,24]$, it can be expected that type II cells would be considerably more enriched in disaturated phosphatidylcholine. Indeed, it was found that $44-61 \%$ of the phosphatidylcholine in type II cells from adult rat lung is disaturated $[25,26]$, whereas a much lower percentage (28\%) has been reported for whole adult rat lung [27]. Based on these data, it can be calculated that the type II cells are at least 7.5 -fold enriched in disaturated phosphatidylcholine content.

Table II shows the pool sizes of the cofactors involved in the CDPcholine pathway in whole lung and type II cells. It can be seen that, in contrast to the other cofactors, the type II cells are not highly enriched in ATP and ADP. The ratio of CTP to CMP in type II cells is directly the opposite of that in whole lung. The method used in the present study to measure inorganic pyrophosphate [21] is nol sensitive enough to detect any inorganic pyrophosphate in either type II cells or whole lung. A similar negative finding was obtained when inorganic pyrophosphate was measured according to the method described by Johnson et al. [28]. This result suggests that the pool sizes of inorganic pyrophosphate in both type II cells and whole lung are less than 2 pmol per $\mu$ g DNA.

\section{Discussion}

Previous studies on the rate-limiting reaction in pulmonary phosphatidylcholine synthesis have shown that the choline phosphate pool in rat and rabbit lung is much larger than the CDPcholine pool, which suggests that the formation of CDPcholine by cholinephosphate cytidylyltransferase is limiting [4-6]. A similar finding with respect to pool sizes was deduced from labelling experiments of rat lung type II cells with radioactive choline [9]. In the present study we have extended this earlier work [4,9] and confirmed that the (unlabelled) choline phosphate pool in alveolar type II cells is much larger than the intracellular choline and CDPcholine pool.

The overall pattern of the pool sizes of the choline-containing metabolites in whole rat lung is very similar to that reported previously [4]. The level of choline is somewhat lower than that found earlier [4], but agrees with the choline content reported by Gail and Farrell [29] for rat lung, using a method similar to that reported here. The levels of CDPcholine and phosphatidylcholine are slightly greater than previously reported for rat lung [4].

The alveolar type II cells are extremely enriched in intracellular choline and its intermediates. It should be noted, however, that the levels of choline-containing metabolites in the isolated type II cells do not necessarily reflect the situation in vivo. It is plausible that the levels in the isolated cells will be influenced by the choline concentration of the culture medium. However, the choline concentration of the medium used in the present study is only 3-fold higher than the concentration of choline reported for rat plasma [30]. Hence, it appears unlikely that the enrichment of type II 
cells in choline derivatives could be due entirely to the increased choline content of the culture medium.

The most notable enrichment in pool size was observed in the content of choline phosphate and CDPcholine. It should be emphasized that the values of CDPcholine for the isolated type II cells should be interpreted with caution. If the CDPcholine content is calculated from the ratio of radioactive choline incorporated into choline phosphate and CDPcholine at the time of isotopic equilibrium after $24 \mathrm{~h}$ of incubation together with the measured choline phosphate values, the true concentration of CDPcholine would be $61.6 \pm 8.4$ pmol per $\mu \mathrm{g}$ DNA (data not shown). Consequently, assuming the correctness of this latter result, the type II cells would be most strongly enriched in choline phosphate, which would be consistent with the idea that cholincphosphate cytidylyltransferase catalyzes the rate-limiting reaction in the biosynthesis of phosphatidylcholine [9]. On the other hand, an alternative explanation for the enrichment of type II cells in CDPcholine may be that under the incubation conditions utilized, the equilibrium of the reaction catalyzed by cholinephosphotransferase is shifted toward the backward direction. Several studies have shown that the cholinephosphotransferase reaction is reversible in different organs (31-34), including lung [33,34]. The hypothesis that the cholinephosphotransferase reaction may be reversed is supported by the observation that the cells contain high levels of CMP. It has been demonstrated that in the presence of CMP lung microsomes catalyze the conversion of microsomal phosphatidylcholine to diacylglycerols and CDPcholine $[33,34]$.

The levels of the high energy nucleotides, ATP and CTP, are comparable to those reported previously $[35,36]$ for rat and rabbit lung. The concentration of CMP agrees well with that found for rabbit lung [36]. Interestingly, the type II cells are highly enriched in cytidine nucleotides but not in adenosine nucleotides. An explanation may be that cytidine nucleotides are mainly present in lung cells which have a high rate of phosphatidylcholine synthesis, such as alveolar type II cells, while adenosine nucleotides are more evenly distributed among all lung cells. The present results may indicate that, compared to other lung cells, type II cells are not greatly enriched in milochondrial activity.

The inability to detect inorganic pyrophosphate in either whole lung or type II cells implies the presence of very active pyrophosphatases. In this respect it may be noted that Infante and Kinsella [37] have suggested that pyrophosphatases promote the formation of CDPcholine by favoring the forward reaction of cholinephosphate cylidylyltransferase.

On the basis of thermodynamic calculations, it has been suggested that in rat liver [38] and chick embryonic muscle cells [39] the choline kinase and cholinephosphate cytidylyltransferase enzymes are far from equilibrium, while the terminal enzyme cholinephosphotransferase is near equilibrium. Similar kinetic analysis of the present data of pool sizes in alveolar type II cells leads to the same conclusion. Both choline kinase and cholinephosphate cytidylyltransferase catalyze non-equilibrium reactions, indicating that either enzyme may be regulatory in the type II cells. The indications that the cholinephosphotransferase reaction may be reversed make it unlikely that this enzyme is regulatory in the type II cells. In previous studies $[9]$ it has been shown that labelled choline taken up by the type II cells is rapidly phosphorylated to choline phosphate. This finding and the present observation that the choline phosphate pool is much larger than the intracellular choline pool argue against a rate-limiting role of choline kinase. No satisfactory explanation can as yet be offered for the irreversibility of the choline kinase reaction. Nevertheless, it is evident from the previcus [9] and present findings that cholinephosphate cytidylyltransferase regulates the flux of choline in adutl lung type II cells.

\section{Acknowledgements}

The investigations described in this paper were supported in part by the Netherlands Foundation for Chemical Research (S.O.N.) with financial aid from the Netherlands Organization for the Advancement of Pure Research (Z.W.O.) and the Netherlands Asthma Foundation (Nederlands Astma Fonds) and by the United States National Institutes of Health (HL-27372, Specialized Center of Research in Pediatric Lung Disease). We thank 
Mrs. E.A.J.M. Schuurmans for excellent technical assistance.

\section{References}

1 King, R.J. and Clements, J.A. (1972) Am. J. Physiol. 223, 715-726

2 Kennedy, E.P. (1961) Fed. Proc. 20, 934-940

3 Rooney, S.A. (1979) Trends Biochem. Sci. 4, 189-191

4 Tokmakjian, S. and Possmayer, F. (1981) Biochim. Biophys. Acta $666,176-180$

5 Possmayer, F., Casola, P.G., Chan, F., MacDonald, P., Ormseth, M.A. Wong, T., Harding, P.G.R. and Tokmakjian, S. (1981) Biochim. Biophys. Acta 664, 10-21

6 Tokmakjian, S., Haines, D.S.M. and Possmayer, F. (1981) Biochim. Biophys. Acta 663, 557-568

7 Vance, D.E. and Choy, P.C. (1979) Trends Biochem. Sci. 4, 145-148

8 Goerke, J. (1974) Biochim. Biophys. Acta 344, 241-261

9 Post, M., Batenburg, J.J., Schuurmans, E.A.J.M. and Van Golde, L.M.G. (1982) Biochim. Biophys. Acta 712, 390-394

10 Mason, R.J., Williams, M.C., Greenleaf, R.D. and Clements, J.A. (1977) Am. Rev. Resp. Dis. 115, 1015-1026

11 Mason, R.J., Williams, M.C. and Dobbs, L.G. (1977) in Pulmonary Macrophage and Epithelial Cells, Proc. Annu. Hanford Biol. Symp., 16th Energy Res. Dev. Admin. Symp. Ser. 43 (Sanders, C.L., Schneider, R.P., Dagle, G.E. and Ragan, M.A., eds.), pp. 280-297, Technical Information Center, Energy Research and Development Administration, Springfield, VA.

12 Mason, R.J. and Williams, M.C. (1977) Am. Rev. Resp. Dis. 115 Suppl., 81-91

13 Batenburg, J.J., Longmore, W.J. and Van Golde, L.M.G. (1978) Biochim. Biophys. Acta 529, 160-170

14 Bligh, E.G. and Dyer, W.J. (1959) Can. J. Biochem. Physiol. 37, 911-917

15 Hildebrand, J.G. (1974) in Methods of Enzymatic Analysis (Bergmeyer, H.U., ed.), Vol. 4, pp. 1819-1824, Academic Press, New York

16 Bartlett, G.R. (1959) J. Biol. Chem. 234, 466-468

17 Burton, K. (1956) Biochem. J. 62, 315-323

18 Giles, K.W. and Meyers, A. (1965) Nature 206, 93
19 Strehler, B.L. (1974) in Methods of Enzymatic Analysis (Bergmeyer, H.U., ed.), Vol, 4, pp. 2113-2126, Academic Press, New York.

20 Choy, P.C., Whitehead, F.W. and Vance, D.E. (1978) Can. J. Biochem. 56, 831-835

21 Putnins, R.F. and Yamada, E.W. (1975) Anal. Biochem. 68, 185-195

22 Pande, S.V. (1976) Anal. Biochem. 74, 25-34

23 Smith, F.B. and Kikkawa, Y. (1978) Lab. Invest. 38, 45-51

24 Mason, R.J. and Dobbs, L.G. (1980) J. Biol. Chem. 255, 5101-5107

25 Batenburg, J.J. and Van Golde, L.M.G. (1979) in Reviews in Perinatal Medicine (Scarpelli, E.M. and Cosmi, E.V., eds.), Vol. 3, pp. 73-114, Raven Press, New York

26 Mason, R.J. and Williams, M.C. (1980) Biochim. Biophys. Acta $617,36-50$

27 Montfoort, A., Van Golde, L.M.G. and Van Decnen, L.L.M. (1971) Biochim. Biophys. Acta 231, 335-342

28 Johnson, J.C., Shanoff, M. Bass, S.T., Boezi, J.A. and Hansen, R.G. (1968) Anal. Biochem. 26, 137-145

29 Gail, D.B. and Farrell, P.M. (1978) Lung 155, 255-263

30 Zeisel, S.H. and Wurtman, R.J. (1981) Biochem. J. 198, $565-570$

31 Kanoh, H. and Ohno, K. (1973) Biochim. Biophys. Acta $326,17-25$

32 Goracci, G., Francesangel, E., Horrocks, L.A. and Porcellati, G. (1981) Biochim. Biophys. Acta 664, 373-379

33 Van Heusden, G.P.H. and Van den Bosch, H. (1982) Biochim. Biophys. Acta 711, 361-368

34 Sarzala, M.G. and Van Golde, L.M.G. (1976) Biochim. Biophys. Acta 441, 423-432

35 Post, M., Batenburg, J.J., Schuurmans, E.A.J.M., Oldenborg, V., Van der Molen, A.J. and Van Golde, L.M.G. (1983) Lung 161, 349-359

36 Quirk, J.G., Bleasdale, J.E., MacDonald, P.C. and Johnston, J.M. (1980) Biochem. Biophys. Res. Commun. 95, 985-992

37 Infante, J.P. and Kinsella, J.E. (1978) Biochim. Biophys. Acta 526, 440-449

38 Infante, J.P. (1977) Biochem. J. 167, 847-849

39 Sleight, R. and Kent, C. (1980) J. Biol. Chem. 255, 10644-10650 